\title{
Health research institutional mapping: an Eastern Mediterranean Regional perspective
}

Ahmed Mandil, Fadi El-Jardali², Samar El-Feky' ${ }^{1}$ Mohamed Nour ${ }^{1}$, Mazen Al-Abbar ${ }^{1}$ and Lama Bou-Karroum²

${ }^{1}$ World Health Organization Regional Office for the Eastern Mediterranean, Cairo, Egypt (Correspondence to: A. Mandil: mandila@who.int). ${ }^{2}$ Faculty of Health Sciences, American University of Beirut, Beirut, Lebanon.

\begin{abstract}
Background: Research-conducive environments are mandatory for planning, implementing and translating research findings into evidence-informed health policies.
\end{abstract}

Aim: This study aimed at comprehensive situation analysis of health research institutions in the Region.

Methods: We collected data on: institutional characteristics, research scope, capacity building, ethics, governance and resources.

Results: We contacted 575 institutions, of which, 223 (38.8\%) responded, indicating that they conducted population research $(82 \%)$. Reported studies were mostly in medicine, public health and epidemiology, while reported capacity building mainly focused on scientific writing $(20.6 \%)$, research proposal writing $(18 \%)$ and quantitative research methods (17\%). Most institutions reported having collaborating partners ( $82 \%$ - predominantly national (77\%). Sixty-four percent of institutions received their own funding, with $48 \%$ reporting always having access to national databases.

Conclusion: Governments in the Eastern Mediterranean Region and international funding agencies are called upon to support health research production through increasing allocated support and capacity building in health research.

Keywords: mapping; health research; institutions; Eastern Mediterranean Region

Citation: Mandil A; El-Jardali F; El-Feky S; Nour M; Al-Abbar M; Bou-Karroum L. Health research institutional mapping: an Eastern Mediterranean Regional perspective. East Mediterr Health J. 2018;24(2):189-197. https://doi.org/10.26719/2018.24.2.189.

Received: 11/10/17; accepted: 08/01/18

Copyright @ World Health Organization (WHO) 2018. Some rights reserved. This work is available under the CC BY-NC-SA 3.0 IGO license (https:// creativecommons.org/licenses/by-nc-sa/3.o/igo).

\section{Introduction}

Health research is an integral component in developing health systems, understanding the roots and consequences of poor health, as well as anticipating and mitigating the effects of various factors on health. Promoting and fostering an environment conducive for health research is mandatory for planning, designing and implementing research and for sharing, using and translating its findings into evidence-informed health policies and cost-effective interventions (1).

Mapping studies have been attempted in Africa (2), Canada (3), Europe (4), Latin America and the Caribbean (5). Recent studies in the World Health Organization (WHO) Eastern Mediterranean Region have revealed that the performance of health systems research is weak across all sectors, including governance, finance, workforce, medical and other technology, health information and service delivery. Such studies have referred to critical deficits in stewardship and translation of research into policy and practice, and often absence of an identified research agenda based on emerging priorities (6-8). It should be emphasized that there were prior attempts for health research mapping in the Region, but such studies were not comprehensive and only involved some member states (9-11), or were of institutional (rather than national) scope (10). Thus, to plan effectively for supporting health research to address current priorities and challenges in the Region, comprehensive mapping was deemed essential.

This mapping study aimed to review the scope of existing health research in the Region and identify the challenges that need to be addressed to promote health research further. More specifically, the study aimed to synthesize prior mapping attempts for health research in the Region; to provide a rationale for carrying out comprehensive situation analysis of the range of health research institutions; and to identify possible gaps in the research cycle (research question, objectives, methods, data management, report writing and knowledge translation).

\section{Methods}

The study followed a cross-sectional approach over 2 phases: the first was to synthesize prior attempts for mapping health research in the Eastern Mediterranean Region; and the second was to conduct a mapping survey of health research institutions in the Region.

\section{Synthesis of prior mapping exercises in the Region}

For synthesis of prior attempts, a literature search was carried out to identify prior mapping attempts for 
health research in the Region, using databases (Medline, PubMed, Academic Search Complete, WHO Index Medicus for the Eastern Mediterranean Region and Google Scholar); websites [WHO, Council on Health Research and Development (COHRED), Alliance for Health Policy and Systems Research]; and reference lists of relevant studies. Search terms used to search the different databases are found in Appendix 1; Medline search strategies for mapping exercises in the Region and globally are found in Appendix 2; and identified studies are listed in Appendix 3.

\section{Health research institutions mapping survey}

For the health research institutional mapping survey, a tool was developed to provide a more comprehensive situation analysis of the landscape of health research in the Region at the country level. The tool was a modified version of tools used in previous regional/ global mapping exercises $(3,6,10-15)$ and consisted of 6 sections, each comprising several questions on: background information; institutional characteristics; scope of research; training and capacity building; ethics, leadership and governance; and resources (human, financial and technical). In addition, participants were asked to provide narrative remarks reflecting challenges (national, financial, human resources and technical) faced when conducting research within their respective institutions. The tool was pilot-tested to ensure validity and reliability and estimate the time of completion using a guiding protocol for pilot testing. Pilot testing resulted in refinement of some questions.

Focal persons were identified in each of the study countries by the WHO Regional Office for the Eastern Mediterranean to assist data collection. Upon their approval to collaborate, detailed information was provided to them including the overall approach and data collection tool. The responsibilities of the focal person were to assist with: identifying institutions and corresponding focal points in each country; and encouraging institutions to complete the survey tool and submitting online within a specific deadline. The focal persons also validated the final list of institutions after elimination of duplicates and nonresearch centres.

A comprehensive process was developed to establish and validate a database for targeted health research institutions and contact persons. The process went through the following steps: (1) identifying WHO contact lists of health institutions; (2) designing a comprehensive database schema with a unified structure; (3) converting all lists to the unified structure and synthesizing them into the contacts database with a unique identifier and a link to its origin (1415 contacts from 14 sources); (4) reviewing to exclude nonresearch institutions, which resulted in selection of the 575 targeted institutions; (5) validating to exclude duplicates; and (6) sharing the contact list with focal persons for final review and amendments. Data were collected between July 2015 and March 2016.

An automated tool was developed by WHO to send a cover message to each targeted participant/institution, explaining the requirement and communicating the authentication credentials for accessing the online form. Ethical clearance to conduct the study was obtained from the Regional Office. Tool users received continuous communication to ensure clarity of the tasks and to facilitate data collection and reporting to the core team. Survey tools were developed on an interactive web interface using WHO DataCol version 4.4 software.

\section{Data analysis}

Data from the survey were analysed using SPSS version 24 for quantitative data. Descriptive analysis including means and standard deviations were used as appropriate. Testing for significant differences across groups was done using the $\chi^{2}$ test.

\section{Results}

\section{Synthesis of prior mapping exercises in the Eastern Mediterranean Region}

The search identified 67 health research mapping exercises, of which, 35 were conducted in the Region (Appendix 3). Upon screening this subgroup, the following gaps were identified. (1) Scope of mapping: mapping addressed some institutional categories (e.g., academic institutions, nonacademic research centres, governmental bodies, international organizations and nongovernmental organizations), focusing on certain parts of the research cycle and support systems. (2) Methodology: among the 35 screened articles, 29 used bibliometric analyses to assess health research

\begin{tabular}{ll}
\hline $\begin{array}{l}\text { Appendix } 1 \text { Search terms for identifying prior mapping exercises } \\
\text { Search terms used for mapping }\end{array}$ & \multicolumn{1}{c}{$\begin{array}{c}\text { Mapping, production or productivity, assessment, assessing, baseline, } \\
\text { (situation or bibliometric) analysis }\end{array}$} \\
Search terms used for health research & $\begin{array}{l}\text { Health research (captures: health policy and systems research, health services research, } \\
\text { population health research, public health research) }\end{array}$ \\
Search terms for the Eastern Mediterranean Region & $\begin{array}{l}\text { (middle east or east }{ }^{*} \text { Mediterranean) } \\
\text { (Egypt or Libya or morocco or Tunisia or Afghanistan or Bahrain or Iran or Iraq or } \\
\text { Jordan or Kuwait or Lebanon or Oman or Qatar or (Saudi Arabia) or Syria or (united } \\
\text { emirates) or Yemen or Pakistan or Palestine or Somalia or Sudan or Djibouti) } \\
\text { Arab countr* }\end{array}$ \\
\hline
\end{tabular}




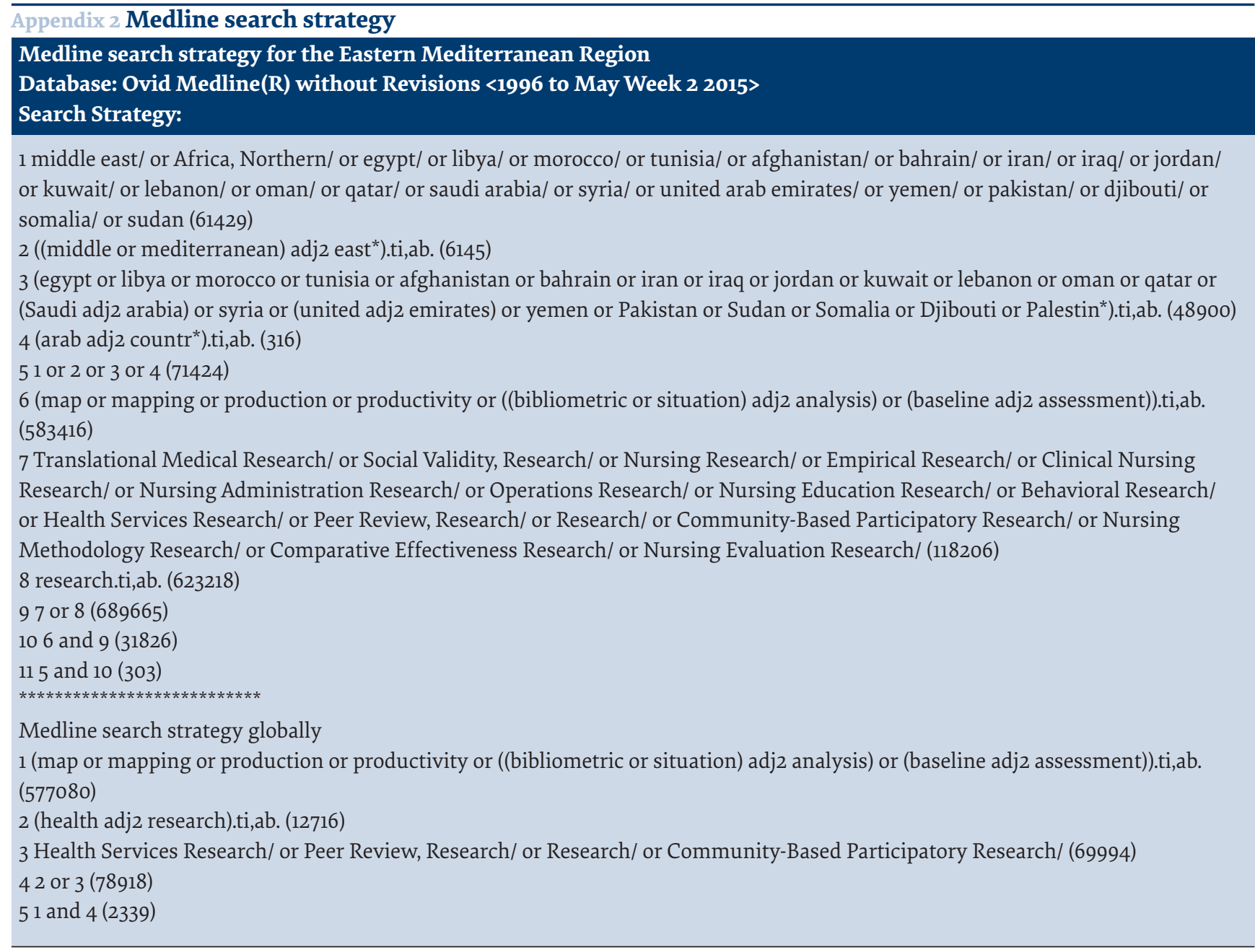

production. Only 6 studies used a cross-sectional method with surveys to map the situation of health research in the Region. (3) Coverage of countries in the Region: the cited studies focused on a subset of Member States in the Region (maximum of 10). No single study has assessed all 22 countries, to gain a comprehensive understanding of the state of health research in the Region. (4) Type of health research: most mapping exercises were topic specific such as mental health research, noncommunicable diseases, nutrition and dietetics. Several articles focused on assessment of biomedical research. Only a few focused on health policy and systems research or public health research.

Outcomes of the synthesis of prior mapping exercises in the Region paved the way and provided a rationale for carrying out comprehensive situation analysis of health research institutions in the Region, identifying possible gaps in the research cycle.

\section{Health research institutions mapping survey}

A total of 575 facilities were contacted across 22 countries in the Region, of which, 223 (38.8\%) responded to the survey (Table 1). Respondents' positions were diverse, including directors (27\%), deans (15.3\%) and chairpersons (12.6\%); most of them reported holding a $\mathrm{PhD}$ or $\mathrm{MD}$ $(84.7 \%)$, while only $10.5 \%$ reported holding an MS or MA.

\section{Institutional characteristics}

About half of the respondent centres were academic research institutions (44.7\%), mostly (59.8\%) established after 2001. Organizational sectors were mostly public (64.2\%); noting that $40 \%$ of nonacademic research institutions were nongovernmental.

\section{Scope of research}

The majority of responding institutions reported conducting population/public health research (84.2\%); $76.9 \%$ reported conducting social/behavioural research; and $74.6 \%$ reported conducting clinical/experimental research.Academic research centres/institutes conducted the majority of research in the areas shown in Table 2, but the differences from schools and nonacademic centres were only significant for biomedical/basic science research, clinical experimental research and population/ public health research.

\section{Training and capacity building}

The most commonly reported topics of capacity building sessions were scientific writing/publishing (20.1\%), health research proposal writing/funding (18.8\%) and quantitative research methods (15.9\%). Institutions hosted in high-income countries in the Region reported 


\section{Appendix 3 Mapping attempts in the Eastern Mediterranean Region}

- El-Jardali F, Jamal D, Ataya N, Jaafar M, Raouf S, Matta C, et al. Health policy and systems research in twelve Eastern Mediterranean Countries: a stocktaking of production and gaps (2000-2008). Health Res Policy Syst. 201110 7;9(1):39. https://doi.org/10.1186/1478-4505-9-39 PMID:21978482

- Ghannem H, Becerra-Posada F, IJsselmuiden C, Helwa I., de Haan S. National research for health system mapping in 5 countries in the Eastern Mediterranean region and perspectives on strengthening the systems. East Mediterr Health J. 2011;17(3):260-1.

- Kennedy A, Khoja TA, Abou-Zeid AH, Ghannem H, IJsselmuiden C; WHO-EMRO/COHRED/GCC NHRS Collaborative Group. National health research system mapping in 10 Eastern Mediterranean countries. East Mediterr Health J. 2008 May-Jun;14(3):502-17. PMID:18720615

- Naqvi HA, Khan MM. Mapping exercise of mental health research and researchers in Pakistan. J Pak Med Assoc. 2007 Jun;57(6):294-8.

- Sweileh WM, Zyoud SH, Al-Jabi SW, Sawalha AF. Substance use disorders in Arab countries: research activity and bibliometric analysis. Substance Abuse Treat Prevent Policy. 2014;9:33. https://substanceabusepolicy.biomedcentral. com/articles/10.1186/1747-597X-9-33

- A study of national health research in selected countries of WHO Eastern Mediterranean Region: Egypt, Islamic Republic of Iran, Pakistan and Sudan. Cairo: World Health Organization Regional Office for the Eastern Mediterranean; 2004 (http://apps.who.int/iris/bitstream/10665/119700/1/dsa215.pdf).

issuing calls for proposals annually (37.8\%), while institutions hosted within high-to-middle- and low-tomiddle-income countries did not report issuing such calls $(28.8 \%$ and $28.4 \%$, respectively). We used the World Bank classification for countries (https://datahelpdesk. worldbank.org/knowledgebase/articles/906519-world- bank-country-and-lending-groups).

\section{Incentives}

Institutions were asked about the type of incentives offered to staff to engage in health research. The most reported incentive (50/109) was financial, which included

\begin{tabular}{|c|c|c|c|}
\hline Country & Target & Received & Response rate (\%) \\
\hline Afghanistan & 15 & 1 & 6.7 \\
\hline Bahrain & 6 & 3 & 50.0 \\
\hline Djibouti & 4 & 0 & 0.0 \\
\hline Egypt & 63 & 15 & 23.8 \\
\hline Iraq & 45 & 13 & 28.9 \\
\hline Islamic Republic of Iran & 120 & 66 & 55.0 \\
\hline Jordan & 20 & 11 & 55.0 \\
\hline Kuwait & 7 & 2 & 28.6 \\
\hline Lebanon & 13 & 8 & 61.5 \\
\hline Libya & 11 & 4 & 36.4 \\
\hline Morocco & 19 & 12 & 63.2 \\
\hline Oman & 7 & 7 & 100.0 \\
\hline Pakistan & 56 & 20 & 35.7 \\
\hline Palestine & 17 & 9 & 52.9 \\
\hline Qatar & 17 & 5 & 29.4 \\
\hline Saudi Arabia & 29 & 10 & 34.5 \\
\hline Somalia & 8 & 3 & 37.5 \\
\hline Sudan & 42 & 7 & 16.7 \\
\hline Syrian Arab Republic & 17 & 7 & 41.2 \\
\hline Tunisia & 21 & 7 & 33.3 \\
\hline United Arab Emirates & 16 & 10 & 62.5 \\
\hline Yemen & 22 & 3 & 13.6 \\
\hline Total & 575 & 223 & 38.8 \\
\hline
\end{tabular}




\begin{tabular}{lccc}
\hline Table 2 Association between institution type and scope of research & & School/faculty \\
& $\mathbf{n ( \% )}$ & $\begin{array}{c}\text { Academic research centre/ } \\
\text { institute }\end{array}$ & $\begin{array}{c}\text { Nonacademic research } \\
\text { centre/institute }\end{array}$ \\
Biomedical/basic sciences research & $37(16.4)$ & $\mathbf{n}(\%)$ & $\mathbf{n}(\%)$ \\
Clinical experimental research & $43(19.0)$ & $60(16.0)$ & $10(15.9)$ \\
Social/behavioural research & $49(21.7)$ & $81(21.6)$ & $12(19.0)$ \\
Population/public health research & $51(22.6)$ & $77(20.5)$ & $13(20.6)$ \\
Health policy/systems research & $46(20.4)$ & $89(23.7)$ & $15(23.8)$ \\
Total & 226 & $68(18.1)$ & $13(20.6)$ \\
\hline
\end{tabular}

${ }^{a}$ This total exceeds the total number of respondent institutions, as categories were not mutually exclusive.

providing grants to researchers, scholarships, awards, monetary incentives and supporting publishing in peerreviewed journals. The second most reported incentive was linking research activities and publications to academic promotion (25/109). Otherincentives reported by respondents included participation in local and regional conferences, collaboration with local and international research centres and organizations, technical support, paid research leave, and training.

\section{Leadership and governance}

The majority of institutions reported having an advisory board (65\%), especially public and nongovernmental organizations. The types of advisory board members were: general public or service recipients (e.g., citizens, patients and clients) (35/314, 11.2\%; 314 exceeds the total number of respondent institutions, as categories are not mutually exclusive); other academic faculties/schools/research institutes (86, 27.4\%); policy-makers in government (43, 13.7\%); representatives of health care institutions (55, 17.5\%); representatives of donor agencies (17, 5.4\%); representatives of health professional associations (45, 14.3\%); and representatives of nongovernmental organizations $(33,10.5 \%)$.

The majority of institutions reported having collaborating partners (81.4\%), with national collaborators comprising a majority (70.7\%) (regional $66.4 \%$, international, 55.4\%). Nonacademic research centres/institutes, nongovernmental organizations and high-income countries were all more likely to have collaborating partners.

\section{Research ethics boards}

The majority of institutions reported having an ethics review board (73.5\%); mostly reported by high-income countries. The areas represented in the ethics board included medicine (58.8\%), health systems (44.4\%) and public health $(41.3 \%)$, in addition to statistics, epidemiology and sociology. The majority of institutions (70.8\%) reported having a policy that outlined the structure and function of the ethics review committee, but low-to-middle-income countries were significantly less likely to have such policies (58\%). About two thirds (63.7\%) of institutions reported providing training or continuing education to scientists/researchers/new members on research on health ethics. Verification and auditing procedures are outlined in Table 3. Only half $(50.9 \%)$ the sampled institutions reported having policies for conducting onsite audits of their research ethics committee rules. Only 35\% conducted internal/ external assessment of the function of the research ethics committee as part of quality improvement.

\section{Human, technical and financial resources}

Gender distribution of researchers was reported to be almost the same across participating institutions (i.e., almost equal numbers of men and women), but the average number of $\mathrm{PhD}$ holders was higher than those with an MS, BS/BA or MD. International institutions were found to have a significantly higher number of MS degree holders than public institutions had.

Health research funding sources were: own institution (145/458, 31.7\%; 458 exceeds the total number of respondent institutions, as categories are not mutually exclusive); local public institution (89, 19.4\%); regional public institution (49, 10.6\%); WHO (47, $10.3 \%)$; international aid agency (36, 7.9\%); local private institution (35, 7.6\%); pharmaceutical company $(34,7.4 \%)$; other United Nations agency (32, 7.0\%); and regional private institution $(25,5 \cdot 5 \%)$.

The majority of institutions reported always having computers $(84.5 \%)$, telephones $(78.8 \%)$, internet connections $(76.1 \%)$, printers $(75.7 \%)$ and scanners $(67.7 \%)$ at the disposal of their researchers. Only $45.6 \%$ reported always having access to national databases, while $32.3 \%$ reported always having access to international databases. Participant institutions reported providing IT support (73.5\%), staff for research on health $(65.9 \%)$, research management (57.1\%), and health proposal writing services (52.2\%) (Table 4). Respondent institutions reported that their research laboratories were predominantly clinical (41.0\%) or biotechnology (36.2\%) laboratories.

\section{Challenges facing institutions conducting health research (qualitative feedback)}

At the national level, some respondents (12/51) indicated that lack of awareness of policy-makers of the importance of research is one of the challenges facing health research 


\begin{tabular}{|c|c|c|c|}
\hline & $\begin{array}{c}\text { No } \\
\text { n (\%) }\end{array}$ & $\begin{array}{c}\text { Yes } \\
\text { n (\%) }\end{array}$ & Total \\
\hline $\begin{array}{l}\text { Does your institution have policy for conducting onsite audits to ensure } \\
\text { researchers' compliance to Research Ethics Committee rules? }\end{array}$ & $111(49.1 \%)$ & $115(50.9 \%)$ & 226 \\
\hline Does your institution have conflict of interest policies for research? & $116(51.3 \%)$ & $110(48.7 \%)$ & 226 \\
\hline $\begin{array}{l}\text { Does your institution provide information to research participants on publicly } \\
\text { accessible websites? }\end{array}$ & $83(36.7 \%)$ & $143(63.3 \%)$ & 226 \\
\hline \multirow{2}{*}{$\begin{array}{l}\text { Does your institution conduct internal/external assessment of Research Ethics } \\
\text { Committee functioning as part of its quality improvement programme? }\end{array}$} & $147(65.0 \%)$ & $79(35.0 \%)$ & 226 \\
\hline & $457 a$ & $447 a$ & \\
\hline
\end{tabular}

${ }^{a}$ This total exceeds the total number of respondent institutions, as categories are not mutually exclusive.

conduct and utilization of its findings. Respondents also reported a lack of national strategy for health research, and a lack of national policies and regulations that govern the conduct of health research. The need to set national research priorities and raise awareness about the importance of research and evidence-informed policymaking was also reported. The limited availability and access to data, mainly governmental data, was another challenge raised by respondents. Other challenges reported included limited national funding and mismatch between funding and national priorities.

Atthefinanciallevel,mostrespondents (61/89) reported limited funds available for health research, including limited internal funding and lack of grant management systems. Other reported financial challenges included mismatch between funding opportunities and priorities, sustainability of funding, and competitive aspects of international funding.

At the human resources level, almost half the respondents (33/69) reported a shortage of and challenges in recruitment of health researchers, as well as difficulty in retaining qualified researchers, research assistants and associates (i.e., brain drain). Respondents raised the need to build capacities and skills of health researchers, especially on research methods, writing proposals, complementary and integrative medicine research, and health policy and systems research.

At the technical level, the challenges mostly reported by respondents included: limited availability of laboratories facilities, equipment and devices; limited skills and capacities of the staff; and lack of collaboration between the research institutions and other national, regional and international institutions. Sanctions were also reported to challenge some institutions from adopting new technologies, buying equipment and accessing websites.

\section{Discussion}

This mapping exercise provides an overview of the scope of existing health research cycles and support systems in the Eastern Mediterranean Region. We found that most institutions reported undertaking public health research followed by clinical research, and fewer institutions reported undertaking health policy and systems research. This is in line with a previous mapping exercise that showed the low production of health policy and systems research in the Region (8). Most institutions reported having collaborating partners $(82 \%)$, predominantly national $(77 \%)$, and to a lesser extent international collaborators (55.4\%). Most participating institutions were public and received internal funding (64\%).

We identified several challenges that undermine health research in the Region. Both quantitative and qualitative data reflected limited national, regional and international funding to institutions conducting health research. This indicates that investment in health research is still low in the Region. Limitations in national funding can be attributed to multiple reasons. National governments and policy-makers, especially in high- and upper-middle-income countries, might still be allocating

\begin{tabular}{|c|c|c|c|}
\hline Table & $\begin{array}{c}\text { No } \\
\text { n (\%) }\end{array}$ & $\begin{array}{c}\text { Yes } \\
\text { n (\%) }\end{array}$ & Total \\
\hline $\begin{array}{l}\text { Does your institution provide research management services (include staff involved in } \\
\text { financial management and control of research funds)? }\end{array}$ & $97(47.8 \%)$ & $118(57.1 \%)$ & 215 \\
\hline Does your institution provide research on health proposal writing services? & $108(47.8 \%)$ & $118(52.2 \%)$ & 226 \\
\hline $\begin{array}{l}\text { Does your institution have other support staff in research on health (i.e., data } \\
\text { collection, management, analysis, etc.)? }\end{array}$ & $77(34.1 \%)$ & $149(65.9 \%)$ & 226 \\
\hline Does your institution have information technology support staff? & $60(26.5 \%)$ & $166(73.5 \%)$ & 226 \\
\hline Total & $342^{a}$ & $551^{\mathrm{a}}$ & - \\
\hline
\end{tabular}

${ }^{a}$ This total exceeds the total number of respondent institutions, as categories are not mutually exclusive. 
limited budgets for health research (6). Policy-makers in these countries may be also unaware of the importance of health research in improving health systems and public health, as reported by some respondents. These countries might also be lacking national strategies and policies that govern health research and define national health research priorities as reported by several respondents. One can also speculate that policy-makers are rarely engaged in health research as only $29.3 \%$ of institutions reported having policy-makers on their advisory board. This finding is in line with another mapping exercise conducted in the Region that showed that only 3 of 10 surveyed countries reported setting national health research priorities, and only 2 countries had a dedicated national health research policy (11). Another study from the Region also revealed the poor engagement of policymakers in health research, with only $16 \%$ of researchers interacting with policy-makers and stakeholders in priority setting, and only $20 \%$ involved them in their research (16). Another reason for limited national funding might be the financial inability of the country to provide a high budget for health research, especially in low- and middle-income countries. The limited international funding can be explained by the weak institutional capacity to attract funds, in terms of grant management, writing proposals, access to international databases and shortage of skilled human resources, as the findings of the present study show. Some of the reported reasons for this shortage were the difficulty in recruiting and retaining qualified researchers, mainly research assistants and associates, and the brain drain caused by emigration.

The present study reflected the findings from the first comprehensive survey involving all Member States of the Region. The survey also targeted all the health research institutional categories (public, private, academic and nonacademic) and all types of health research (from biomedical to health systems research). It utilized a thorough pilot-tested survey that was based on research evidence and comprised different sections that covered different aspects of health research cycle and support systems.
Although the study had a high target for sampling facilities, the response rate was $38.8 \%$. Despite this, the results provide insight into different aspects of health research. In some countries, focal people were more successful in terms of access to respondents and responsiveness to complete the survey itself. In some instances, questions required respondents to report on their personal perceptions; these questions may have been subject to social desirability responses. Additionally, we were unable to consider the context for understanding the situation of health research institutions, due to the cross-sectional nature of the study and random response of respondent institutions. Hence, the outcomes of the survey should be assessed with caution, in spite of the wide spectrum of respondent institutions from different countries in the Region. We believe that after sharing results with Members States, more health research institutions will come forward and respond to the survey, providing a better spectrum of the health research cycle in the Region.

\section{Conclusion and recommendations}

Governments in the Region and international funding agencies are called upon to support health research through increasing support and capacity building in health research. Health research institutions in the Region should work on developing strategies to retain qualified researchers and building capacities of existing ones. The institutions are also called upon to strengthen their capacities, including grant management systems and access to international databases. This will increase their ability to attract international funding and increase research productivity. As the study showed limited international collaboration, institutions should recognize the importance of such collaboration in advancing and exchanging knowledge and strengthening research capacity and expertise (17).

\section{Acknowledgements}

This survey and related research work was supported by the WHO Regional Office for the Eastern Mediterranean. Completion of this project would not have been possible without the continuous support and encouragement of $\mathrm{Dr}$ Ala Alwan, former Regional Director; Dr Mahmoud Fikri, late Regional Director; Dr Jaouad Mahjour, Acting Regional Director/Director of Programme Management, and Dr Arash Rashidian, Director, Information, Evidence and Research Department. The following experts supported country-specific databases and encouraged response of participating health research institutions: Dr Najibullah Safi, Afghanistan; Dr Randah Hamadeh, Bahrain; Dr Sherine Shawky, Egypt; Dr Reza Majdzadeh, Islamic Republic of Iran; Dr Nada Alwan, Iraq; Dr Raeda Abu Al Rub, Jordan; Dr Hanan Badr, Kuwait; Dr Salim Adib, Lebanon; Dr Azza Greiw, Libya; Dr Asma El Alami Felousse, Morocco; Dr Adhra Al Mawali, Oman; Dr Assad Hafeez and Dr Saima Hamid, Pakistan; Dr Niveen Abu Rmeileh, Palestine; Dr Ziad Mahfoud, Qatar; Dr Haifa Wahabi, Saudi Arabia; Dr Samira Abdel Rahman, Sudan; Dr Hyam Bashour, Syrian Arab Republic; Dr Chokri Arafa, Tunisia; Dr Ghada Al Tajir, United Arab Emirates, and Dr Ali Assabri, Yemen. Ms Diana Jamal assisted with manuscript reviews.

\section{Funding: None.}

Competing interests: None declared. 


\section{Cartographie institutionnelle de la recherche en santé : perspective régionale pour la Méditerranée orientale}

\section{Résumé}

Contexte : Des environnements favorables à la recherche sont nécessaires pour planifier, mettre en œuvre et traduire les résultats de recherche en politiques de santé reposant sur des bases factuelles.

Objectif : La présente étude visait à mener une analyse de situation des établissements de recherche en santé dans la Région.

Méthodes : Nous avons recueilli des données sur les caractéristiques institutionnelles, le champ des recherches, le renforcement des capacités, l'éthique, la gouvernance et les ressources.

Résultats : Nous avons contacté 575 établissements, sur lesquels $223(38,8 \%)$ ont répondu qu'ils avaient effectué des recherches en population ( $82 \%)$. Les études traitées concernaient principalement la médecine, la santé publique et l'épidémiologie ; le renforcement des capacités signalé portait principalement sur l'écriture scientifique (20,6\%), la rédaction des propositions de recherche $(18 \%)$ et les méthodes de recherche quantitative (17\%). La plupart des établissements signalaient avoir des partenaires de collaboration (82\%), principalement au niveau national (77\%). Soixante-quatre pour cent des établissements recevaient leur propre financement, et $48 \%$ mentionnaient avoir toujours accès aux bases de données nationales.

Conclusion: Les gouvernements des pays de la Région de la Méditerranée orientale et les bailleurs de fonds internationaux sont appelés à soutenir la production de la recherche en santé en augmentant le soutien et le renforcement des capacités alloués en matière de recherche en santé.

$$
\begin{aligned}
& \text { وضع خريطة لمؤسسات البحوث الصحية: منظور لإقليم شرق المتوسط }
\end{aligned}
$$

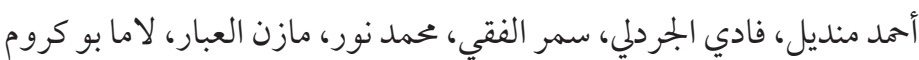

الخلفية: يمثل توفّر بيئة مؤ اتية للبحوث أمراً ضرورياً لتخطيط البحوث وتنفيذها وتر جمة نتائجها إلى سياسات صحية تستند إلى الدلائل.

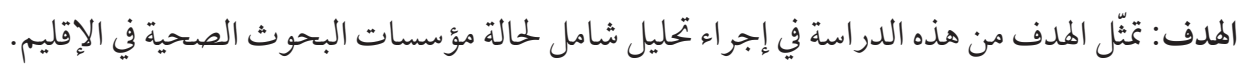

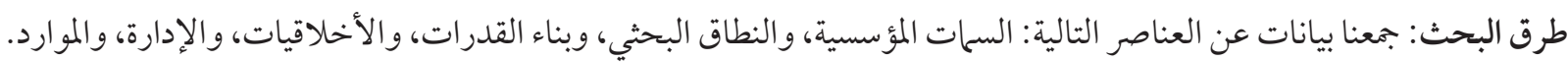

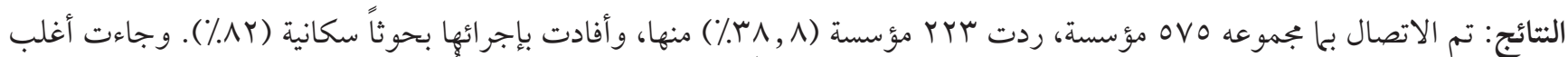

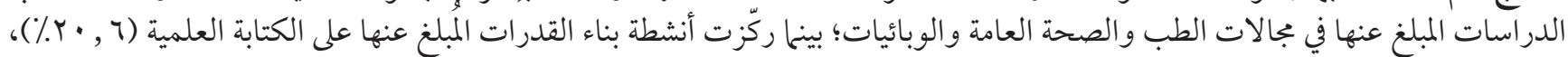

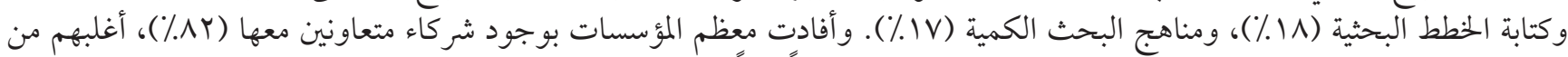

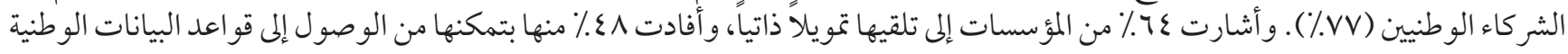
بشكل دائم.

الاستتناج: حكومات إقليم شرق المتوسط وو كالات التمويل الدولية مدعوة لدعم إنتاج البحوث الصحية عن طريق زيادة الدعم المخصّص وبناء القدرات في مجال البحوث الصحية في الإقليم.

\section{References}

1. Report on the expanded meeting for members of the Advisory Committee on Health Research and research experts to discuss integrating research in shaping the future of health in the Eastern Mediterranean Region. Cairo, Egypt, 16-18 February 2014. Cairo: World Health Organization Regional Office for the Eastern Mediterranean; 2014 (http://applications.emro.who.int/docs/ IC_Meet_Rep_2014_EN_15356.pdf?ua=1, accessed 24 January 2018).

2. Hofman K, Kanyengo C, Rapp B, Kotzin S. Mapping the health research landscape in Sub-Saharan Africa: a study of trends in biomedical publications (2009). J Med Libr Assoc. 2009 Jan;97(1):41-4. http://doi.org/10.3163/1536-5050.97.1.007 PMID:19158994

3. Dobrow MJ, Costa S, Israr S, Chafe R. Mapping health services and policy research settings in Canada: following the money, the publications and the interest. Healthc Policy. 2010 Nov;6(2):84-98. PMID:22043225

4. Clarke A, Gatineau M, Grimaud O, Royer-Devaux S, Wyn-Roberts N, Le Bis I, et al. A bibliometric overview of public health research in Europe. Eur J Public Health. 2007;17 Suppl 1:43-9. https://doi.org/10.1093/eurpub/ckmo63 PMID:17666422

5. Becerra-Posada F, Minayo M, Quental C, de Haan S. National research for health systems in Latin America and the Caribbean: 
moving towards the right direction? Health Res Policy Syst. 2014 Mar 6;12:13. https://doi.org/10.1186/1478-4505-12-13 PMID:24602201

6. Ismail SA, McDonald A, Dubois E, Aljohani FG, Coutts AP, Majeed A, et al. Assessing the state of health research in the Eastern Mediterranean Region. J R Soc Med. 2013 Jun;106(6):224-33. https://doi.org/10.1258/jrsm.2012.120240 PMID:23761582

7. Mandil A, Chaaya M, Saab D. Health status, epidemiological profile and prospects: Eastern Mediterranean Region. Int J Epidemiol. 2013 Apr;42(2):616-26. https://doi.org/10.1093/ije/dyto26 PMID:23505252

8. El-Jardali F, Jamal D, Ataya N, Jaafar M, Raouf S, Matta C, et al. Health policy and systems research in twelve Eastern Mediterranean Countries: a stocktaking of production and gaps (2000-2008). Health Res Policy Syst. 2011 10 7;9(1):39. https://doi. org/10.1186/1478-4505-9-39 PMID:21978482

9. A study of national health research in selected countries of WHO Eastern Mediterranean Region: Egypt, Islamic Republic of Iran, Pakistan and Sudan. Cairo: World Health Organization Regional Office for the Eastern Mediterranean; 2004 (http:// applications.emro.who.int/dsaf/dsa215.pdf, accessed 24 January 2018).

10. National health research system mapping in the Eastern Mediterranean Region. A study of ten countries. Cairo: World Health Organization Regional Office for the Eastern Mediterranean; 2008 (http://apps.who.int/iris/handle/10665/116554, accessed 24 January 2018).

11. Kennedy A, Khoja TA, Abou-Zeid AH, Ghannem H, IJsselmuiden C; WHO-EMRO/COHRED/GCC NHRS Collaborative Group. National health research system mapping in 10 Eastern Mediterranean countries. East Mediterr Health J. 2008 MayJun;14(3):502-17. PMID:18720615

12. Gonzalez Block MA, Mills A. Assessing capacity for health policy and systems research in low and middle income countries. Health Res Policy Syst. 200301 13;1(1):1. https://doi.org/10.1186/1478-4505-1-1 PMID:12646072

13. Adam T, Ahmad S, Bigdeli M, Ghaffar A, Røttingen J-A. Trends in health policy and systems research over the past decade: still too little capacity in low-income countries. PLoS One. 2011;6(11):e27263. https://doi.org/10.1371/journal.pone.0027263 PMID:22132094

14. Lavis JN, Robertson D, Woodside JM, McLeod CB, Abelson J; Knowledge Transfer Study Group. How can research organizations more effectively transfer research knowledge to decision makers? Milbank Q. 2003;81(2):221-48. PMID:12841049

15. Gholami J, Majdzadeh R, Nedjat S, Nedjat S, Maleki K, Ashoorkhani M, Yazdizadeh B. How should we assess knowledge translation in research organizations; designing a knowledge translation self-assessment tool for research institutes (SATORI). Health Res Policy Syst. 2011 Feb 22;9:10. http://doi.org/10.1186/1478-4505-9-10

16. El-Jardali F, Lavis JN, Ataya N, Jamal D. Use of health systems and policy research evidence in the health policymaking in eastern Mediterranean countries: views and practices of researchers. Implement Sci. 2012 Jan 11;7:2. http://doi.org/10.1186/1748-5908-7-2

17. Lucas AO. International collaboration in health research. Bull World Health Organ. 2005 Jul;83(7):482. PMID:16175818 